\title{
Impact of various factors on in vitro investigation of rare mangrove species Sonneratia apetala Buch.-Ham. (Myrtales: Lythraceae) and Suaeda maritima (L.) Dumort (Caryophyllales: Amaranthaceae)
}

\author{
Abdul Kader ${ }^{1}$, Sankar Narayan Sinha ${ }^{2}$ and Parthadeb Ghosh ${ }^{1 * *}$ \\ ${ }^{1}$ Cytogenetics \& Plant Biotechnology Research Unit. Department of Botany. University \\ of Kalyani. Kalyani - 741235, Nadia. West Bengal, India. \\ *Email: pdggene@rediffmail.com. \\ ${ }^{2}$ Environmental Microbiology Research Laboratory. Department of Botany. University \\ of Kalyani, Kalyani -741235, Nadia. West Bengal, India.
}

\begin{abstract}
Recent studies have showed the importance and destruction of mangroves. So their restoration through tissue culture study is urgently required because in vivo propagation is plagued with unforeseen obstacles. In vitro investigation of mangroves found to be suitable material for salt tolerant mechanism studies and anti stress gene isolation. This study describes for the first time in vitro approach for rare species Sonneratia apetala Buch.-Ham. (Myrtales: Lythraceae) and herb species Suaeda maritima (L.) Dumort (Caryophyllales: Amaranthaceae) through callus. For this investigation, as a source of explants various part (leaf, intermodal and nodal segments) of both mangroves were used. These explants were cultured in various types of media (MS, LS, WPM, X and $\mathrm{B}_{5}$ ) with different combination of phytohormones (2, 4-D and NAA with BAP in combination). We also examined the effect of $\mathrm{NaCl}$ and seasons on callus initiation and growth. The highest rate of callus formation was obtained with nodal explants in MS medium supplemented with $1.5 \mathrm{mg} . \mathrm{L}^{-1} \mathrm{NAA}$ and $0.5 \mathrm{mg} . \mathrm{L}^{-1}$ BAP in combination and $1 \mathrm{mg} \cdot \mathrm{L}^{-1} \mathrm{NAA}$ and $0.5 \mathrm{mg} \cdot \mathrm{L}^{-1} \mathrm{BAP}$ in combination for Sonneratia apetala and Suaeda maritime, respectively. We also found that callus initiation rate and growth decreased with increasing $\mathrm{NaCl}$ concentration higher than $80 \mathrm{mM}$ and $120 \mathrm{mM}$ for Sonneratia apetala and Suaeda maritima, respectively in MS media. This study also found that monsoon season was best time for in vitro investigation of mangroves. The results presented here give an insight into the development of in vitro investigation suitable for mangroves. The initiated callus could be restored in low salaine or devoid of salaine land.
\end{abstract}

Keywords: Culture media screening; Callus culture; Mangrove; Salt tolerance; Sonneretia apetala; Suaeda maritima.

\section{Introduction}

Mangrove is a typical ecosystem in the intertidal area from tropical to
Received

Jan. 1, 2016

Accepted

May 30, 2016

Released

June 30, 2016

Open Acess

Full Text Article

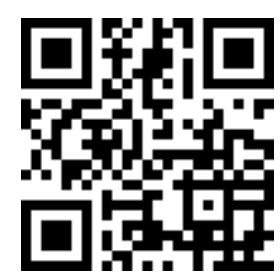

subtropical muddy beaches worldwide. It is considered as low-cost and high-efficiency wetland systems for the treatment of municipal wastewater (Tam and Wong, 
1996) and for remediation of heavy metalpolluted marine environments (MacFarlane et al., 2003). It has critical ecosystem functions such as coastal protection, land stabilization and $\mathrm{CO}_{2}$ fixation (Ren et al., 2009). However destruction of mangrove forest is noticed due to natural and anthropogenic uses (Alongi, 2002). For mangrove restoration many have planted propagules and seeds which depend on natural yields. Therefore it is not possible to get enough numbers of good propagules and seeds all over the year. Recently there is shortage of mangrove seed source (Komiyama et al., 1996). In these circumstances, the alternative method is tissue culture study to get enough number of micropropagated plantlet. Mangrove species are physiologically unique in their adaptations to such water logged and saline condition. Crop scientists, studying the unique adaptation pattern of mangroves, are keen to impart these unique characters in food crops by breeding or biotechnological means (Fukomoto et al., 2004) as salinity and water logging are among the major environmental threats with serious implication on food, fuel and fibre production, especially in arid and semiarid regions (Dagar, 2005). Besides, about onethird of all agricultural lands are becoming saline (Dagar, 2005). To understand the salt and water logging tolerance theoretically or biochemically, callus or cell culture of mangroves may provide promising result. However there are scanty literatures are available on some mangrove species because they are much recalcitrant for tissue culture study (Fukomoto et al., 2004, Kawana and Sasamoto, 2008). During in vitro studies explants frequently turn brown or black shortly after inoculation and result in tissue death (Kathiresan, 1990) due to presence of high amount of tannin and phenolic compounds in mangroves (Ravi and Kathiresan, 1990).

The Sonneratia apetala Buch.Ham. (Myrtales: Lythraceae) is a true mangrove tree from Sonneratiaceae family found in all over the mangrove region of the world and are considered as invasive species of mangrove (Tian et al., 2009, Naskar and Bakshi, 1987, Ren et al., 2009). This species is reported to improve soil fertility and having medicinal property like antioxidant, antimicrobial and cytotoxic activity (Ren et al., 2009). The leaf of this species is used to treat hepatitis (Banerjee et al., 2008, Jaimini et al., 2011). The fruit of this species is consumed by local people of mangrove region after cooking or other preparations. Additionally ripe fruits are used to treat parasites and half ripe fruit for cough (Banerjee et al., 2008 and Jaimini et al., 2011). Shete et al. (2007) reported that the aerial part of this species has the potentiality for the bioaccumulation of $\mathrm{Pb}$ and $\mathrm{Zn}$.

The Suaeda maritima (L.) Dumort (Caryophyllales: Amaranthaceae) is an annual, succulent, salt-marsh mangrove annual herb, with semi-cylindrical leaves from Chenopodiaceae family grows in very alkaline and saline moist soils (Polić et al., 2009, Ravikumar et al., 2011). It is found in the sea cost of Asia, Europe, North and South America and Australia too (Polić et al., 2009). The leaf of this species is used to treat hepatitis and having medicinal properties like antiviral, antibacterial, antioxidant and hepatoprotective activity (Singh et al., 2012).

Keeping the deforestation, tissue culture problem, medicinal and economical value of these plants in mind, we described a preliminary study of micropropagation and degree of salt tolerant, through callus culture, for preservation and production of micropropagated plant for future restoration at degraded areas. To our knowledge, this is the first report of in vitro investigation of these species with systematic study.

\section{Materials and methods}

\section{Plant material}

Different explants from mature plants were collected at various seasons all over the year from Gosaba region $\left(88^{\circ} 39^{\prime} 46^{\prime \prime} \mathrm{E}\right.$ and $\left.22^{\circ} 15^{\prime} 45^{\prime \prime} \mathrm{N}\right)$ of Indian Sundarban Mangrove Forest. 


\section{Surface sterilization of explants}

The explants (1-1.5 cm long) were washed with $2 \%(\mathrm{v} / \mathrm{v})$ teepol for $10 \mathrm{~min}$ and rinsed thrice with distilled water, disinfected with $0.15 \%$ (w/v) $\mathrm{HgCl}_{2}$ for $10 \mathrm{~min}$ and again rinsed four times with sterile distilled water. There after the sterilized explants were cut into small segments and aseptically inoculated on different nutrient media. All the experimental procedures were carried out under aseptic conditions in a laminar airflow.

\section{Culture conditions}

The cultures were generally maintained at standard condition with a temperature of $25 \pm 1{ }^{\circ} \mathrm{C}$ under $65 \pm 5 \%$ relative humidity and $16 \mathrm{~h}$ photoperiod under 2000 lux intensity provided by white fluorescent lamps.

\section{regulators used \\ Culture medium and growth}

Four different types of media were used for callus initiation like Murashiege and Skoog (MS) medium (Murashiege and skoog, 1962), Woody Plant medium (WPM, Lloyd and McCown, 1981), Linsmaier and Skoog (LS) medium (Linsmaier and Skoog, 1965) and X medium (Rao et al., 1998). Considering the herb species Suaeda maritima in mind we also included B5 (Gamborg et al., 1968) medium along with other mentioned medium. All media were supplemented with $3 \%(\mathrm{w} / \mathrm{v})$ sucrose and $0.8 \%$ agar powder. The $\mathrm{pH}$ of the medium was adjusted to 5.7 before autoclaving. For induction of callus and determining the degree of salt tolerant mechanism, $\mathrm{NaCl}$ was added in the medium at various concentration of this experiment. The callus initiation rate (the ratio of the number of explants pieces having calli to total number of explants pieces planted in the same culture) was scored about one month after inoculation. To determine the callus growth on $\mathrm{NaCl}$, fresh weight of calli growth (FWG) was measured 60 days after inoculation as $\left(\mathrm{W}_{1}-\mathrm{W}_{0}\right)$ where $\mathrm{W}_{0}$ is the initial inoculation weight and $\mathrm{W}_{1}$ the final weight. For this study we observed two auxin like 2, 4-dichloro phenoxy acetic acid (2,4-D) and $\alpha$-naphthalene acetic acid (NAA) in combination with one cytokinins i.e, 6-benzyladenine purine (BAP).

\section{analysis}

\section{Data collection and statistical}

Each experiment was repeated three times with 13 replicates. Data were analyzed by one way analysis of variance (ANOVA) and the difference between means were scored using Duncan's Multiple Range Test $\mathrm{P} \leq 0.05$ (Duncan, 1955) on the statistical package of SPSS (Version 10).

\section{Results}

\section{initiation}

Selection of explants for callus

Among the different explants used, leaves were not found to be suitable for callusing. Callus was obtained from nodal and internodal segments (Figure 1 and 2).

\section{Screening for suitable culture media and hormonal combinations}

Callus initiation was observed within 2 to 3 weeks after inoculation using different combinations of auxin (NAA) and cytokinin (BAP) in all the media however $\mathrm{X}$ medium required 4 to 5 weeks for callus initiation for both species (Figure 1 and 2). The highest rate of callus formation was obtained in MS medium supplemented with $1.5 \mathrm{mg} \mathrm{L}^{-1} \mathrm{NAA}$ and $0.5 \mathrm{mg} \mathrm{L}^{-1} \mathrm{BAP}$ in combination and $1 \mathrm{mg} \mathrm{L}^{-1} \mathrm{NAA}$ and $0.5 \mathrm{mg} \mathrm{L}^{-1}$ BAP in combination for S. apetala (Table 1) and S. maritima (Table 2 ), respectively. We also tried to initiate callus on 2, 4-D alone or in combination with BAP but there were no response for $S$. apetela. The 2,4-D containing medium showed low callus initiation rate, slow growth and dark brown nature callus for S. maritima (Figure 2). The in vitro shoot induction was obtained from $1 \mathrm{mg} \mathrm{L}^{-1}$ BAP along with both the auxins i.e., NAA and 2,4-D at the concentrations of $1 \mathrm{mg} \mathrm{L}^{-1}$ (Figure 2, Table 2).

From the result it seems that MS medium is superior to other medium for 
callus formations from both species (Figure 1 and 2) similar findings were reported by various author for tissue culture study of other mangrove species (Singh et al., 2004, Kawana and Sasamoto, 2008). Rao et al.
(1998) prepared $X$ medium for the cultivation of Excoecaria agallocha a mangrove species but it was not found to be suitable for callus initiation from both plants.

Table 1. Rate of callus initiation of $S$. apetala in MS medium at different concentrations of plant hormones $(\mathrm{mg} / \mathrm{L})$.

\begin{tabular}{|c|c|c|l|}
\hline NAA & BAP & \% of callus response & Nature of callus \\
\hline \multirow{3}{*}{1.5} & $\mathbf{0 . 5}$ & $\mathbf{6 4 . 0 9} \pm \mathbf{2 . 5 6 ^ { \mathbf { a } }}$ & Hard, Compact, Deep brown \\
\cline { 2 - 4 } & 1.0 & $51.27 \pm 5.12^{\text {abcd }}$ & Hard, Compact, Deep brown \\
\cline { 2 - 4 } & 1.5 & $41.02 \pm 2.56^{\text {cdef }}$ & Hard, Compact, Deep brown \\
\hline \multirow{3}{*}{2.0} & 0.5 & $32.04 \pm 10.01^{\text {ef }}$ & Hard, Compact, Deep brown \\
\cline { 2 - 4 } & 1.0 & $28.20 \pm 5.13^{\text {f }}$ & Hard, Compact, Deep brown \\
\cline { 2 - 4 } & 1.5 & $41.02 \pm 6.78^{\text {cdef }}$ & Hard, Compact, Deep brown \\
\hline \multirow{3}{*}{2.5} & 0.5 & $35.89 \pm 5.13^{\text {def }}$ & Hard, Compact, Deep brown \\
\cline { 2 - 4 } & 1.0 & $43.58 \pm 5.12^{\text {bcdef }}$ & Hard, Compact, Deep brown \\
\cline { 2 - 4 } & 1.5 & $58.97 \pm 5.13^{\text {ab }}$ & Hard, Compact, Deep brown \\
\hline \multirow{3}{*}{3.0} & 0.5 & $48.71 \pm 5.12^{\text {abcde }}$ & Hard, Compact, Deep brown \\
\cline { 2 - 4 } & 1.0 & $48.71 \pm 2.56^{\text {acde }}$ & Hard, Compact, Deep brown \\
\cline { 2 - 4 } & 1.5 & $53.84 \pm 4.43^{\text {abc }}$ & Hard, Compact, Deep brown \\
\hline
\end{tabular}

Means sharing the same letter are not significantly different $(\mathrm{P} \leq 0.05)$ using Duncan's multiple range test.

Table 2 Hormonal combinations (mg/L) of Suaeda maritima callus on MS medium.

\begin{tabular}{|c|c|c|}
\hline Medium & Response percentage & Nature of Callus \\
\hline \multicolumn{3}{|l|}{ 2,4-D+ BAP } \\
\hline $0+0$ & $00.00 \pm 0.00^{\mathrm{g}}$ & - \\
\hline $1.0+0$ & $15.38 \pm 8.87^{\mathrm{fg}}$ & Hard, Compact, deep brown \\
\hline $1.5+0$ & $20.51 \pm 11.17^{\text {ef }}$ & Hard, Compact, deep brown \\
\hline $2.0+0$ & $35.89 \pm 6.78^{\text {cdef }}$ & Hard, Compact, deep brown \\
\hline $1.0+0.5$ & $48.71 \pm 2.56^{\mathrm{abc}}$ & Hard, Compact, deep brown \\
\hline $1.5+0.5$ & $46.15 \pm 4.43^{\mathrm{abcd}}$ & Hard, Compact, deep brown \\
\hline $2.0+0.5$ & $33.32 \pm 6.78^{\text {cdef }}$ & Hard, Compact, deep brown \\
\hline $1.0+1.0$ & $35.89 \pm 5.13^{\text {cdef }}$ & Shoot formation \\
\hline $1.5+1.0$ & $46.15 \pm 4.43^{\mathrm{abcd}}$ & Hard, Compact, deep brown \\
\hline $2.0+1.0$ & $25.63 \pm 2.56^{\mathrm{def}}$ & Hard, Compact, deep brown \\
\hline \multicolumn{3}{|l|}{$\mathrm{NAA}+\mathrm{BAP}$} \\
\hline $1.0+0$ & $33.32 \pm 10.25^{\text {cdef }}$ & Compact, Granular, White \\
\hline $1.5+0$ & $38.45 \pm 4.44^{\text {bcde }}$ & Compact, Granular, White \\
\hline $2.0+0$ & $41.12 \pm 6.76^{\text {bcde }}$ & Compact, Granular, White \\
\hline $1.0+0.5$ & $64.09 \pm 6.78^{\mathrm{a}}$ & Compact, Granular, White \\
\hline $1.5+0.5$ & $43.58 \pm 9.24^{\text {abcd }}$ & Compact, Granular, White \\
\hline $2.0+0.5$ & $38.55 \pm 5.4 .44^{\text {bcde }}$ & Compact, Granular, White \\
\hline $1.0+1.0$ & $58.97 \pm 5.13^{\mathrm{ab}}$ & Shoot formation \\
\hline $1.5+1.0$ & $48.71 \pm 6.78^{a b c}$ & Compact, Granular, White \\
\hline
\end{tabular}

Means sharing the same letter are not significantly different $(\mathrm{P} \leq 0.05)$ using Duncan's multiple range test. 


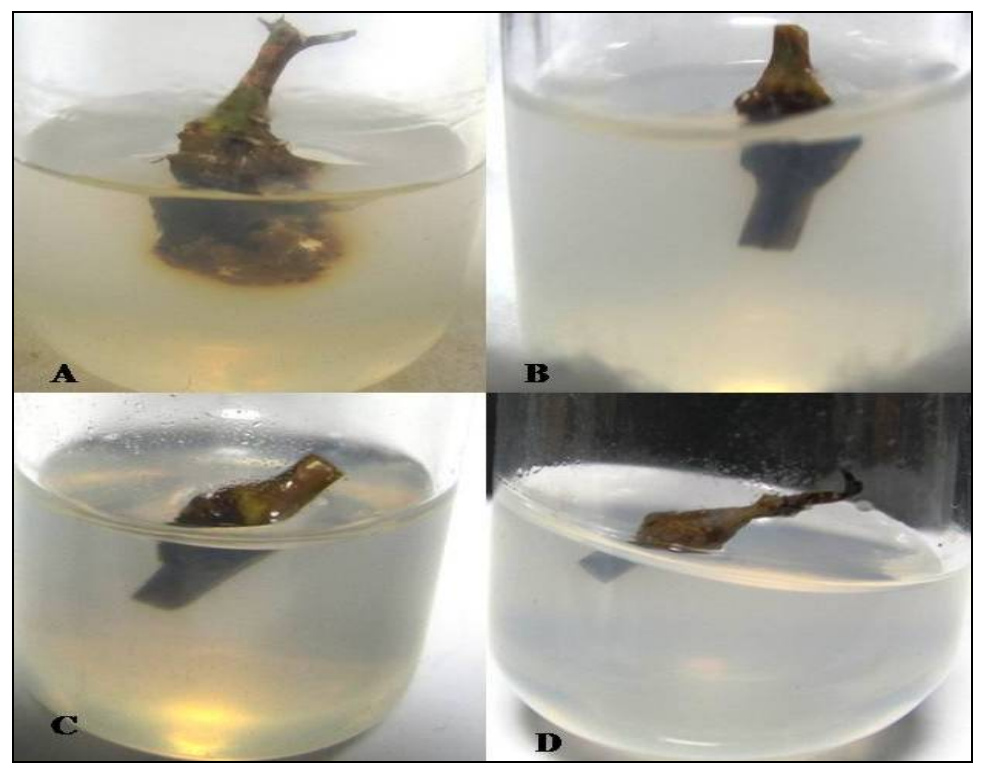

Figure 1. Callus initiation on different medium. A-Callus initiation on MS, B- Callus initiation on LS, CCallus initiation on WPM, D- Callus initiation on X.

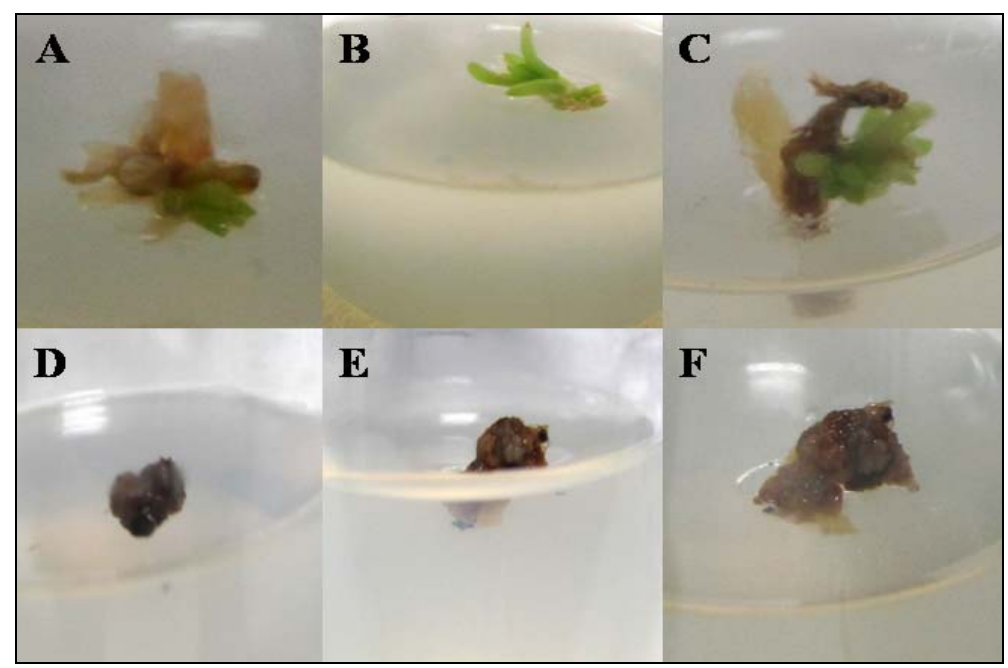

Figure 2. A, B, and C showing Shoot or leaf like structure formation of Suaeda maritima on MS medium, $\mathrm{D}, \mathrm{E}$ and $\mathrm{F}$ showing deep brown callus formation of that species on same medium.

\section{in medium \\ Prevention of browning problem}

Generally media browning is caused by the secretion of phenolic compounds (Roy and Sarkar, 1991) and its callus inhibition activity was discussed by Gill et al. (2004). Browning can be minimized by adding antioxidants or phenol absorbents into medium (Romano and Loucao, 1992) or by transferring explants into new culture media at regular intervals according to some literature (Romano and Loucao, 1992; Altan et al., 2010). However observation revealed during this experiment that addition of extra compounds made the medium complex which interfered with callusing and in latter case the process became time consuming and laborious. So keeping these constraints in mind cultures were kept in dark initially for 7 days and yielded satisfactory result for both the species. 


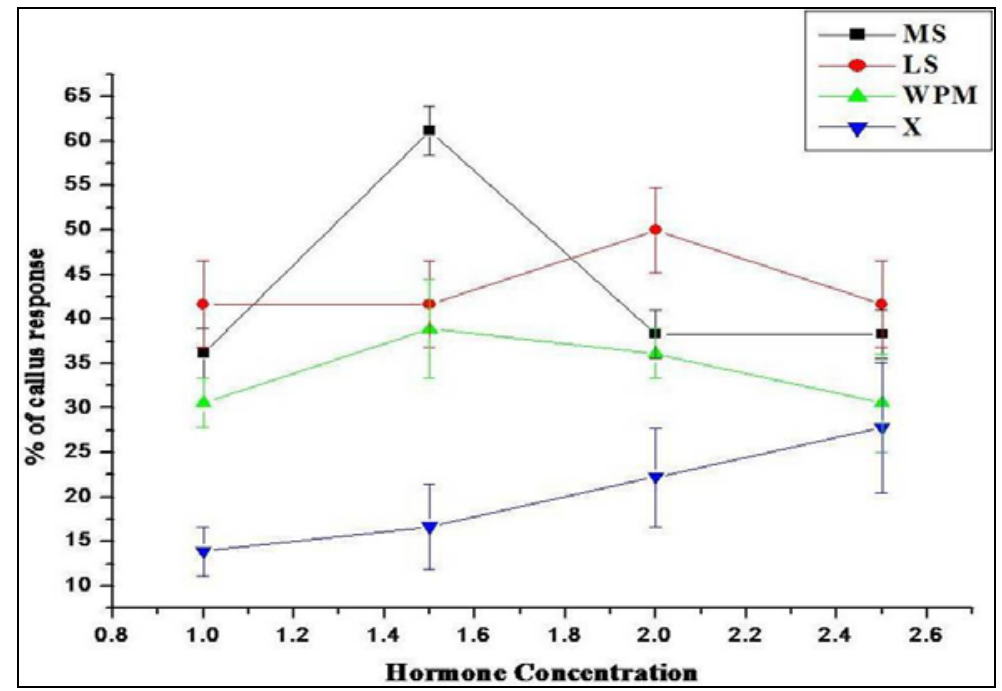

Figure 3. Callus initiation rate of Sonneratia apetala in four different medium under four constant hormone concentrations (mg. $\left.\mathrm{L}^{-1}\right)$.

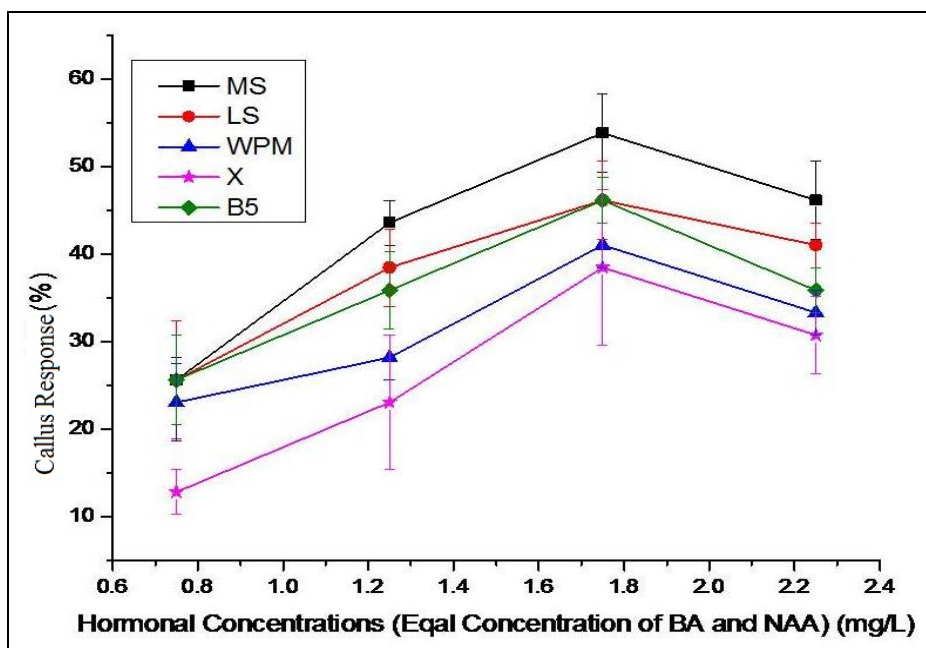

Figure 4 Callus initiation rate of Suaeda maritima in five different medium under four constant hormone concentrations (mg. $\left.\mathrm{L}^{-1}\right)$.

\section{Effect of salt concentration on callus initiation}

The most important characteristic of mangrove plants is their salt tolerance. We examined the effects of the $\mathrm{NaCI}$ concentration on the callus initiation rate. The effects of $\mathrm{NaCI}$ concentration on the callus initiation were compared 60 days after initiation (Figure 3). From this study it was found that the herb mangrove species Suaeda maritima could gave callus well in $120 \mathrm{mM} \mathrm{NaCl}$ (Figure 5). Sonneratia apetala gave highest callus response at the concentration of $80 \mathrm{mM} \mathrm{NaCl}$ (Figure 6). 


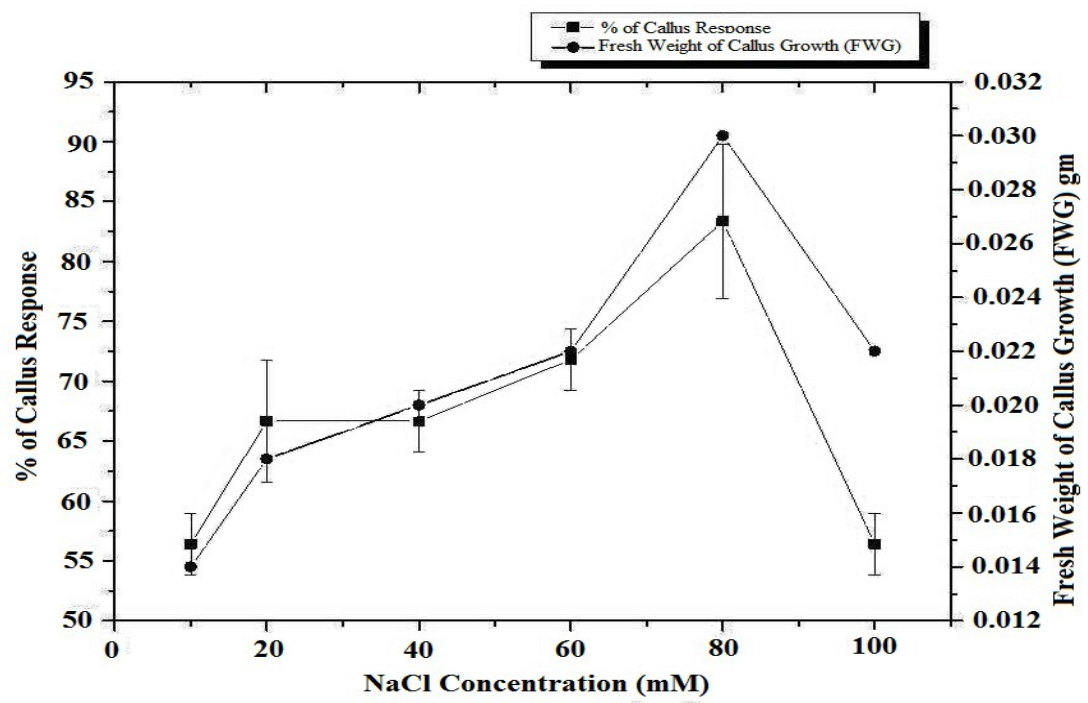

Figure 5. Effect of salt concentration on callus initiation and growth in MS medium using $1.5 \mathrm{mg} . \mathrm{L}-{ }^{1}$ and $0.5 \mathrm{mg} . \mathrm{L}^{-1} \mathrm{NAA}$ and BAP respectively with nodal and intermodal segments of Sonneratia apetala in MS medium.

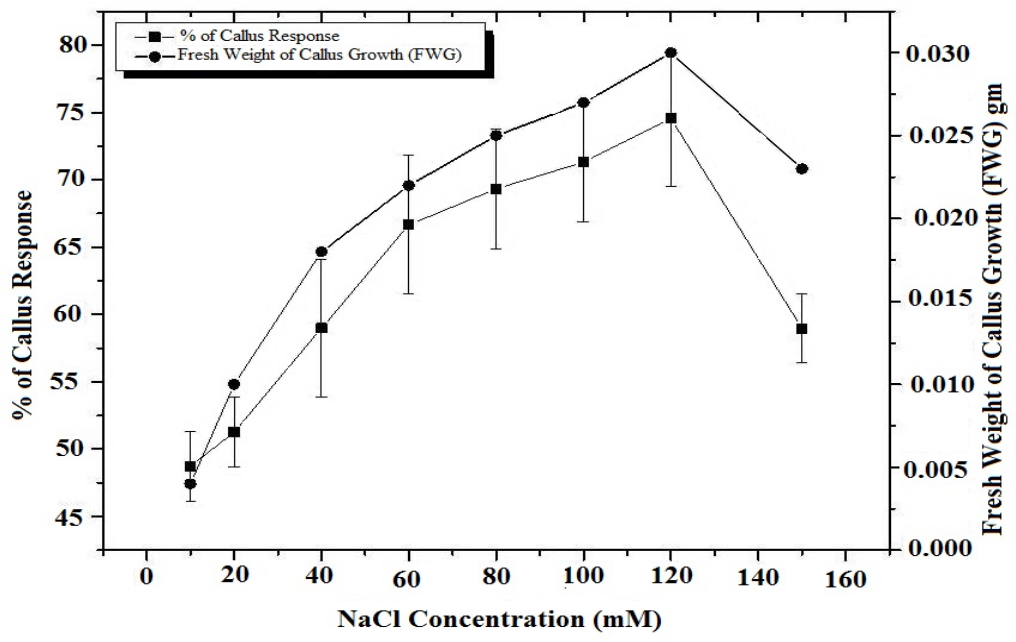

Figure 6. Effect of salt concentration on callus initiation and growth in MS medium using 1 mg.L ${ }^{-1}$ NAA and $0.5 \mathrm{mg} . \mathrm{L}_{-}{ }^{1}$ Bap with nodal and intermodal segments of S. maritima.

\section{Effect of salt concentration on} callus growth

$\mathrm{NaCl}$ effect, on callus growth was determined after 60 days of inoculation. From this experiment it was noticed that the effective $\mathrm{NaCl}$ concentration that gave best callus imitation response was also find to be best for callus growth for each species in this study (Figure 5 and 6).

\section{Seasonal effect on callus formation}

This investigation was carried out in different seasons viz., monsoon (JulySeptember), after monsoon (NovemberFebruary) and before monsoon (MarchJune) to check the seasonal effect for callus formation. From this experiment it was found that for callus culture of this two 
species rainy season was best time (Figure 7 and 8) as compared to other seasons which generally showed explants dormancy and excretion of phenolic compounds vigorously.

\section{Discussions}

It is well developed fact that mangrove callus and suspension cultures are useful in stress related physiological studies (Yasumoto et al., 1999, Kura-Hotta et al., 2001). The present research has opened the way to study the salt tolerance as well as salinity tolerance mechanisms and genetic transformation of mangrove plants at cellular level. It was also noticed in this study that the callusing response of mangrove was very low and maximum callus initiation occurred at lower surface of explants as reported by Singh et al. (2004) and generally initiated callus showed slow growth than other territorial plants and it may be because of their fluctuating and extreme environment of their habitat.

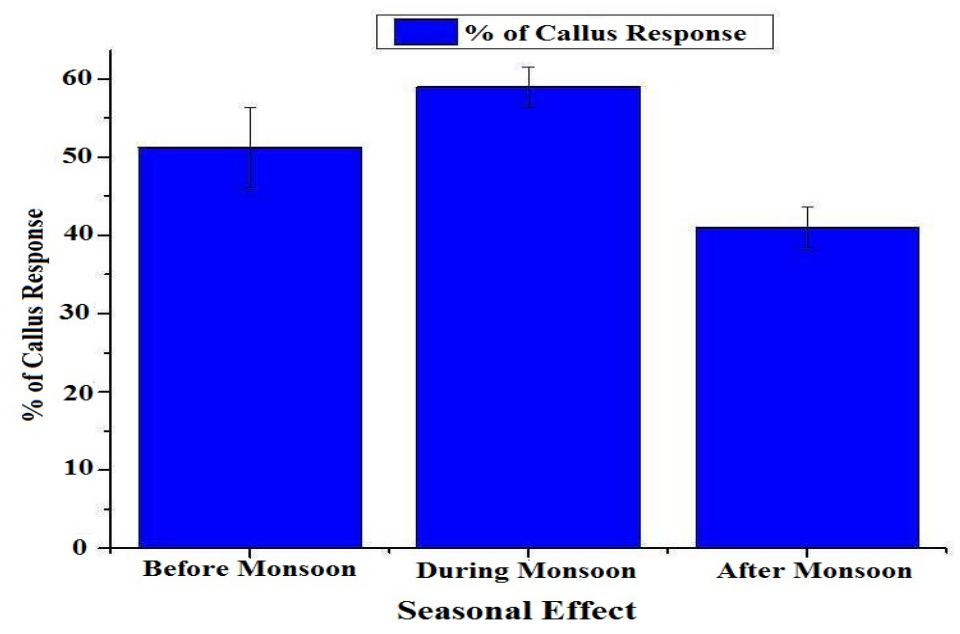

Figure 7. Effect of various seasons on callus initiation of S. apetala in MS medium.

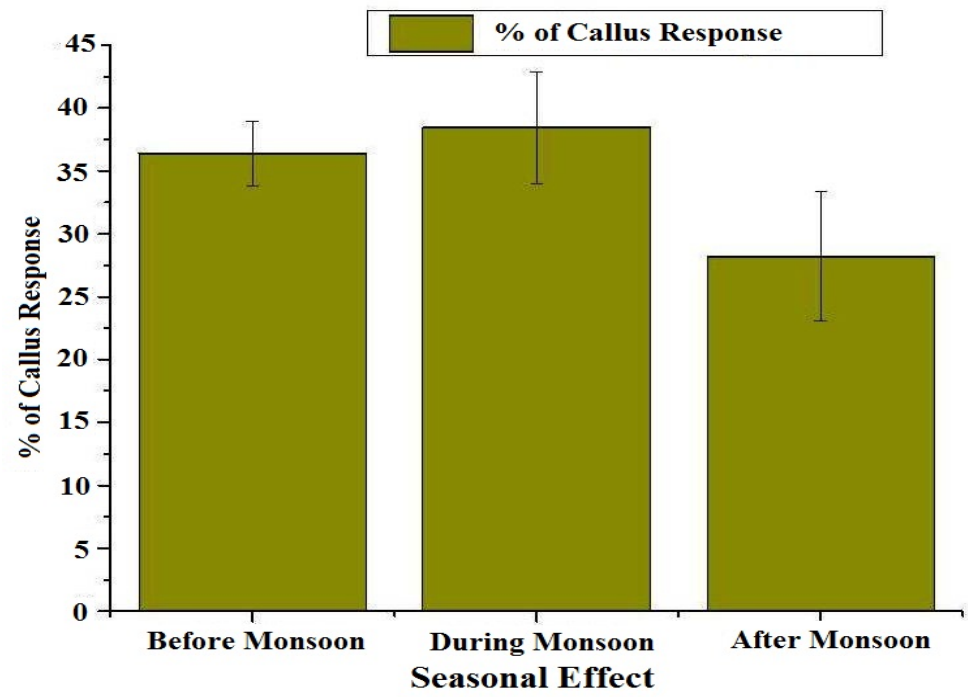

Figure 8. Effect of various seasons on callus initiation of $S$. maritima in MS medium. 
In this experiment two different mangroves showed different pattern of $\mathrm{NaCl}$ tolerance. The literature studies also indicated that $S$. maritima could tolerate more salt concentrations than $S$. apetala. Khan et al. (2000) showed that this genus can grow naturally at $200-400 \mathrm{mM} \mathrm{NaCl}$ concentrations. It may be the reason that species is common on the side of creeks and river beds and plays a dominant role for its better adaptation to the higher degree of salinity and tidal influences (Naskar and Guha Bakshi, 1987). From this experiment it was found that for tissue culture of these species rainy season was best time as compared to other seasons which generally showed explants dormancy and excretion of phenolic compound vigorously. Many tree species which are collected during rainy season (active growth time) shows tremendous growth in in vitro conditions because physiological state of tissue of tree species varies due to variation of season (El-Morsey and Millet, 1996). During winter season the explants showed low viability i.e., dormant in nature and exude maximum phenolic compounds. This may be because the cytosolic ribosome contents are altered in winter metabolism at cellular level in tree species (Haggman, 1986).

The present investigation is a preliminary study for micropropagation and salinity tolerance of $S$. apetala and S. maritima as this is the first documentation of callus induction of these mangroves. However, the efficiency of plant regeneration from callus of mangrove plants is very low (Rao et al., 1998; KuraHotta et al., 2001; Al-Bahrany and Alkhayri, 2003; Hayashi et al., 2009) and it is also very difficult to establish cell culture systems in mangroves, except for few species (Kawana and Sasamoto, 2008). At present we were involved in production of micropropagated plantlets from this callus by transferring them into medium containing high concentration of cytokinin and low concentration of auxin and this may give promising result as the low auxin concentration turns off a certain number of genes which favour embryonic programme (Gill et al., 2004). The shortage or destruction of land in coastal region is another important factor for mangrove destruction (Komiyama et al., 1996). In this regard the present research clearly indicated that the species may be restored in low saline or devoid of saline land as callus is being extensively used for afforestation programmes (Ahuja, 1991). Callus culture give tools for genetic cell transformation by somaclonal variation, induced mutagenesis and genetic engineering which are not only much more rapid than conventional breeding but can also give rise to novel genes and genotypes rather than other traditional methods like mass selection, inbreeding and hybridization which is laborious and time consuming depending on environmental conditions and existing gene pool(s) for plant development (Ahmad et al., 2010). This study can give such type of opportunities for these important mangrove plants.

The results presented here give an insight into the development of in vitro investigation suitable for mangroves. Potentially, higher callus efficiency may be achieved through investigating medium components, hormones other than used in this study, sea salts other than examined in this study.

\section{Acknowledgements}

The authors are grateful to University Grants Commission (UGC) New Delhi, for providing financial assistance to the first author. They are extending their thanks to the head of the department of botany, University of Kalyani for providing DST-FIST central equipment facility. They are also thankful to Dr. Soumen Saha a post doctoral fellow of this department for help in statistical analysis.

\section{Conflict of interests}

The authors declare that they have no conflict of interests.

\section{References}

Ahmad, N.; Faisal, M.; Anis, M.; Aref, I. M. In vitro callus induction and plant regeneration from leaf explants of Ruta graveolens L. South 
African Journal of Botany, v. 76, p. 597-600, 2010.

Ahuja, M. R. Biotechnology in forest trees. Plant Research Development, v. 33, p. 106120, 1999.

Al-Bahrany, A.; Al-Khayri, J. M. Micropropagation of grey mangrove Avicennia marina. Plant Cell, Tissue and Organ Culture, v. 72, p. 87-93, 2003.

Alongi, D. M. Present state and future of the world's mangrove forests. Environmental Conservation, v. 29, p. 331-349, 2002.

Altan, F.; Bürün, B.; Sahin, N. Fungal contaminants observed during micropropagation of Lilium candidum L. and the effect of chemotherapeutic substances applied after sterilization. African Journal of Biotechnology, v. 9, p. 991-995, 2010.

Banerjee, D.; Chakrabarti, S.; Hazra, A. K.; Banerjee, S.; Ray, J.; Mukherjee, B. Antioxidant activity and total phenolics of some mangroves in Sundarbans. African Journal of Biotechnology, v. 7, p. 805-810, 2008.

Dagar, J. C. Ecology, management and utilization of halophytes. Bulletin of the National Institute of Ecology, v. 15, p. 81-97, 2005.

Duncan, D. B. Multiple range and multiple F Test. Biometrics, v. 11, p. 1-42, 1955.

El-Morsey, A.; Millet, B. Rhythmic growth and optimization of micropropagation: the effect of excision time and position of axillary buds on in vitro culture of Citrus aurantium L. Annals of Botany, v. 78, p. 197-202, 1996.

Fukumoto, T.; Nakamura, T.; Suzuki, M.; Ogita, S.; Mimura, T.; Sasamoto, H. Different effects of four salts and $\mathrm{pHs}$ on protoplast culture of a mangrove, Bruguiera sexangula suspension cells, Populus alba leaves and tobacco BY-2 cells. Plant Biotechnology, v. 21, p. 177-182, 2004.

Gamborg, O. L.; Miller, R. A.; Ojima, K. Nutrient requirements of suspension cultures of soybean root cells. Experimental Cell Research, v. 50, p. 151-158, 1968.

Gill, N. K.; Gill, R.; Gosal, S. S. Factors enhacing somatic embryogenesis and plant regeneration in sugarcane (Saccharum officinarum L). Indian Journal of Biotechnology, v. 3, p. 119-123, 2004.

Häggman, H. In vitro translation capacity of ribosomes isolated from the cells of pine buds during cold season. Physiologia Plantaram, v. 66, p. 144-148, 1986.
Hayashi, S.; Kuriyama, S.; Kawana, Y.; Hasegawa, A.; Kurita, A.; Minagawa, R.; Sasamoto, H. Stimulatory effects of sea salts on cell growth in liquid culture of Avicenniaceae mangrove. Plant Biotechnology, v. 26, p. 561564, 2004

Jaimini, D.; Sarkar, C.; Shabnam, A. A.; Jadhav, B. L. Evaluation of antibacterial properties of mangrove plant Sonneratia apetala Buch.-Ham leaf. World Applied Sciences Journal, v. 14, p. 1683-1686, 2011.

Kathiresan, K. Forestry research. Dehradun, India: International Book Distributors, 1990.

Kawana, Y.; Sasamoto, H. Stimulation effects of salts on growth in suspension culture of a mangrove plant, Sonneratia alba, compared with another mangrove, Bruguiera sexangula and non-mangrove tobacco BY-2 cells. Plant Biotechnology, v. 25, p. 151-155, 2008.

Khan, M. A.; Ungar, I. A.; Showalter, A. M. The effect of salinity on the growth, water status, and ion content of a leaf succulent perennial halophyte, Suaeda fruticosa (L.) Forssk. Journal of Arid Environments, v. 45, p. 73-84, 2000.

Komiyama, A.; Santiean, T.; Higo, M.; Patanaponpaiboon, P.; Kongsangchai, J.; Ogino, K. Microtopography, soil hardness and survival of mangrove (Rhizophora apiculata BL.) seedlings planted in an abandoned tin-mining area. Forest Ecology \& Management, v. 81, p. 243-248, 1996.

Kura-Hotta, M.; Mimura, M.; Tsujimura, T.; Washitani-Nemoto, S.; Mimura, T. High salttreatment-induced $\mathrm{Na}^{+}$extrusion and low salt treatment-induced $\mathrm{Na}^{+}$accumulation in suspension cultured cells of the mangrove plant Bruguiera sexangula. Plant Cell and Environment, v. 24, p. 1105-1112, 2001.

Linsmaier, K.; Skoog, F. Organic growth factor requirements of tobacco tissue culture. Plant Physiology, v. 21, p. 487-492, 1965.

Lloyd, G.; McCown, B. Commercially-feasible micropropagation of Mountain laurel, Kalmia latifolia, by use of shoot tip culture. Combined Proceedings, International Plant Propagators' Society, v. 30, p. 421-427, 1981.

MacFarlane, G. R.; Pulkownik, A.; Burchett, M. D. Accumulation and distribution of heavy metals in the grey mangrove, Avicennia marina (Forsk.) Vierh: biological indication potential. Environmental Pollution, v. 123, p. 139-151, 2003.

Murashige, T.; Skoog, F. A revised medium for rapid growth and bioassays with tobacco tissue 
culture. Physiologia Plantarum, v. 15, p. 473497, 1962.

Naskar, K.; Guha Bakshi, D. N. Mangrove swamps of the Sundarbans: an ecological perspective. Naya Prokash, Kolkata, 1987.

Polić, D.; Luković, J.; Zorić, L.; Boža, P.; Merkulov, L.; Knežević, A. Morpho-anatomical differentiation of Suaeda maritima (L.) Dumort, 1827 (Chenopodiaceae) populations from inland and maritime saline area. Central European Journal of Biology, v. 4, p. 117-129, 2009.

Rao, S. C.; Eganathan, P.; Anand, P.; Balakrishna, P.; Reddy, P. T. Protocol for in vitro propagation of Excoecaria agallocha L., a medicinally important mangrove species. Plant Cell Reports, v. 17, p. 861-865, 1998.

Ravi, A. V.; Kathiresan, K. Seasonal variation in gallotannin from mangroves. Indian Journal of Marine Sciences, v. 19, p. 224-225, 1990.

Ravikumar, S.; Gnanadesigan, M.; Jacob, S.; Kalaiarasi, A. Hepatoprotective and antioxidant properties of Suaeda maritima (L.) Dumort ethanolic extracton concanavalin-A induced hepatotoxicity in rats. Indian Journal of Experimental Biology, v. 49, p. 455-460, 2011. Ren, H.; Lu, H.; Shen, W.; Huang, C.; Guo, Q.; La, Z.; Jia, S. Sonneratia apetala Buch.-Ham in the mangrove ecosystems of China: an invasive species or restoration species. Ecological Engineering, v. 35, p. 1243-1248, 2009.

Romano, A.; Martins-Loucao, M. A. Micropropagation of mature cork-oak (Quer cussuber L.): establishment problems. Scientia Genmdensis, v. 18, p. 17-27, 1992.

Roy, S. C.; Sarkar, A. In vitro regeneration and micropropagation of Aloe vera L. Scientia Horticulturae, v. 47, p. 107-113, 1991.

Shete, A.; Gunale, V. R.; Pandit, G. G. Bioaccumulation of $\mathrm{Zn}$ and $\mathrm{Pb}$ in Avicennia marina (Forsk.) Vierh. and Sonneratia apetala
Buch.-Ham. from Urban Areas of Mumbai (Bombay), India. Journal of Applied Sciences and Environmental Management, v. 11, p. 109-112, 2007.

Singh, A.; Chikara, J.; Pandya, J. B. Plant regeneration from callus cultures in Suaeda nudiflora (Wild.) Moq. Indian Journal of Biotechnology, v. 3, p. 454-456, 2004.

Singh, S.; Sharma, S. K.; Mann, R. Antihyperlipidemic activity of Suaeda maritima (L.) Dumortier aerial parts in hypercholesterolemic rats. Journal of Pharmacy Research, v. 5, p. 1400-1402, 2012.

Tam, N. F. Y.; Wong, Y. S. Retention of wastewater-borne nitrogen and phosphorus in mangrove soils. Environmental Technology, v. 17, p. 851-859, 1996.

Tian, M.; Dai, H.; Li, X.; Wang, B. Chemical constituents of marine medicinal mangrove plant Sonneratia caseolaris. Chinese Journal of Oceanology and Limnology, v. 27, p. 288296, 2009.

Yasumoto, E.; Adachi, K.; Kato, M.; Sano, H.; Sasamoto, H.; Baba, S.; Ashii-Iara, H. Uptake of inorganic ions and compatible solutes in cultured mangrove cells during salt stress. In Vitro Cellular \& Developmental Biology, v. 35, p. 82-85, 1999. 
License information: This is an open-access article distributed under the terms of the Creative Commons Attribution License, which permits unrestricted use, distribution, and reproduction in any medium, provided the original work is properly cited.

Braz. J. Biol. Sci., 2016, v. 3, no. 5, p. 181-191. 